\title{
CORRESPONDENCE
}

\section{Genesis of genetics}

SIR - I find the current interest among biologists in the findings of Gorczynski and Steele ${ }^{1,2}$ somewhat surprising, since a report of Lamarckian inheritance was published about 3,000 years ago. It is written that:

"And Jacob took him rods of green poplar, and of the hazel and chestnut tree; and pilled white strakes in them, and made the white appear which was in the rods. And he set the rods which he had pilled before the flocks in the gutters in the watering troughs when the flocks came to drink, that they should conceive when they came to drink. And the flocks conceived before the rods, and brought forth cattle ringstraked, speckled, and spotted." 3

Were these findings ever reproduced? If so, would it not be more appropriate to speak of Jacobinic genetics?

\section{KIRSTEN FISCHER LINDAHL}

Basel Institute for Immunology,

Basel, Switzerland

1. Gorczynski, R.M. \& Steele, E.J. Proc. natn. Acad. Sci U.S.A. 77, 2871-2875 (1980).

2. Gorczynski, R.M. \& Steele, E.J. Nature 289, 678-68। (1981).

3. Genesis Ch. 30 , v. $37-39$.

\section{Ethics of genes}

SIR - It was with considerable surprise and no little confusion that I read Richard Dawkins' letter on genetic determination (Nature 12 February, p.528). In his commendable desire to dissociate himself from the National Front, he has left me totally perplexed about his actual views of the relation between genotype and phenotype. Near the end of his letter, he associates himself with the views of S.J. Gould, that the genetic basis of IQ is "trivially true, uninteresting, and unimportant', Yet earlier in the same letter, he says that genetics is sort of relevant since we may need to "fight all the harder', against genetic tendencies. But in his book The Selfish Gene, Dr Dawkins wrote that we are "robot vehicles blindly programmed to preserve the selfish molecules known as genes" (preface) and that these genes "swarm in huge colonies, safe inside gigantic lumbering robots, sealed off from the outside world . . . manipulating it by remote control. They are in you and me; they control us body and mind"' (p.21).

It really is very vexing. Just as I had learned to accept myself as a genetic robot and, indeed, felt relieved that I was not responsible for my moral imperfections, Dr Dawkins tells me that, after all, I must try hard to be good and that I am not as manipulated as I thought. This is a problem I keep having in my attempt to understand human nature. Professor

Wilson, in his book on sociobiology, assured me that neurobiology was going to provide me with "a genetically accurate and hence completely fair code of ethics"' (p.575). I was euphoric at the prospect that my moral dilemmas at last had a real prospect of resolution, when suddenly my hopes were dashed by an article in which Professor Wilson warned me against the naturalistic fallacy (New York Times 12 October, 1975). You can imagine my perplexity. I do wish I knew what to believe.

Perhaps I am just asking for that foolish consistency which Emerson tells us is the hobgoblin of small minds. But I see that Dr Dawkins himself is uncertain. I can only echo the question he asks in his letter. "Where on earth did the myth of the inevitability of genetic effects come from? Is it just a layman's fallacy, or are there influential professional biologists putting it about?',

ISADORE NABI

Museum of Comparative Zoology,

Harvard University, Cambridge,

Massachusetts, USA

\section{Cancer causation}

SıR - The Epstein-Swartz article which appeared in Naturel (and was essentially identical to the manuscript these authors presented at the autumn meetings of the American Public Health Association in Detroit) will elicit a variety of critical responses from those in the scientific community who are familiar with the specific aetiological links between cancer and the environment.

But here I would like to point out one major fallacy in the Epstein and Swartz piece - their premise (that lifestyle factors have been overstated in discussions of the aetiology of cancer) is based largely on the assumption that occupationally-induced cancers are more prevalent than previously thought. Epstein and Swartz criticize Dr Peto for dismissing "recent estimates of the importance of occupational carcinogens in a report by the US Public Health Service as exaggerated, unsound and unreasonable". This alleged "report" concluded that "as much as $20 \%$ or more" of cancers in the near term and future may reflect past exposure to specific carcinogens in the workplace.

Epstein and Swartz attempt to build up the credibility of this estimate by stating that the report was "prepared by nine named and internationally recognized experts in cancer epidemiology, statistics and carcinogens from three federal research agencies" and go on to add that "there is no basis whatsoever for recent unsubstantiated allegations by Peto and others that all or most of the authors of the government report have disowned or rejected it or its conclusions"

Epstein and Swartz are in error on two points in their discussion of occupational cancer and the so-called "estimates paper". First, nobody except those two authors and perhaps some regulators who wished to bolster their requests for more legal control over occupational chemicals has ever cited the " $20 \%$ " estimate in a serious, scientific context. Second, according to a detailed article by Ruth B. Schwartz in our publication $A C S H$ News and Views " "7 of the 10 scientists responsible for these statistics believe they may be incorrect. Only one scientist defends them as reasonable". Two could not be reached for their opinions. Ms Schwartz's conclusions were based on her in-depth discussions with the various "contributors",

Perhaps the most succinct evaluation of the "estimates paper" on which Epstein and Swartz rely so heavily was made by Sir Richard Doll: "I regard it (the "estimates paper') as scientific nonsense".

Elizabeth M. WhelaN

American Council on Science and Health, New York, USA

1. Epstein, S.S. \& Swartz, J.B. Nature 289, 127-130 (1981)

2. Schwartz, R.B. ACSH News and Views Nov/Dec (1980).

\section{Badger debate}

SIR - Dr Flowerdew's recent letter (Nature 26 February, p.742) makes me wonder what purpose the Mammal Society intended to serve by engaging in what can indeed now be called "the badger controversy". Dr Flowerdew says that the society spoke out because my report provided a "one-sided" interpretation of the evidence ("biased" in Dr Harris's letter of 11 December; Nature, p.532), and because my "categorical" conclusions and

recommendations did not take sufficient account of "the complexity of the problem" But in Dr Harris's letter it was also said that the society was intervening because it was necessary to correct certain "factually misleading statements" that 1 had made. Yet neither letter adduces any new "fact". Those that they use are the ones which I had assembled. Nor did either correspondent spell out any "anomalies" in the story other than those which I had considered. Dr Flowerdew now says that there is no unequivocal evidence that the gassing policy will produce a longterm solution, by which I presume he means stamp out the disease. But no one has ever claimed that it would. Above all, the Mammal Society, on whose behalf Drs Flowerdew and Harris have written, does not propose any alternative policy which the Government could pursue in order to lower the level of the reservoir of the bovine tubercle bacillus in the affected areas of the South West - the existence of which, as Dr Plowright pointed out (Nature 1/8 January, p.8), they first denied, but which in Dr Flowerdew's present letter he, or the Mammal Society, now seems to accept.

I intended no "attack on the Mammal Society and some of its members" - Dr Flowerdew's words - when I asked on what scientific authority the society based its presumed criticisms. The authorities on whom 